\title{
Pogranicze sztuki i architektury. Przestrzeń miejska jako ważny czynnik kształtowania tożsamości
}

\section{Anna Rathman}

\begin{abstract}
STRESZCZENIE
Francuscy encyklopedyści zdefiniowali muzeum jako sumę ludzkiej wiedzy i sztuki, miejsce które może stać się zarazem teatrem i audytorium. Profesor Andrzej Kiciński pisał w swojej książce o muzeach, że zarówno biblioteki jak i muzea stanowią niezbędny i nieodłączny element budowania tożsamości, ale także krajobrazu miasta. Odbiorcy przestrzeni związanych z muzeami stanowią grupę społeczną która tworzy nową jakość poprzez rodzaj wtajemniczenia i wrażliwość na współczesne problemy społeczne i artystyczne.

XX wiek był wiekiem kształtowania się sztuki abstrakcyjnej. Pojawiały się nie tylko artefakty, ale artyści postanowili wykorzystać potencjał widza i wciągnąć odbiorcę w interakcję poprzez nowy rodzaj aktu artystycznego jakim stały się performans i instalacja. Nastąpiło przekroczenie granicy jaką była ściana muzeum - umownej ramy oraz ramy obrazu. Sztuka stała się rodzajem zdarzeń w przestrzeni miejskiej. Tak rozumieją ją twórcy - Leon Tarasewicz czy Krzysztof Wodiczko. Bardzo istotny stał się przekaz społeczny, czasem zaangażowany w aktualne istotne wydarzenia polityczne, ale również jako łączenie ludzi, niezależnie od kultury ich pochodzenia. Architektura także staje się zdarzeniem, gdyż konkretyzuje się przez jej użytkowników - widza - a muzeum jako obiekt jest znakiem w przestrzeni na kulturalnej mapie miasta, kojarzonej przez ludzi, którym bliskie są problemy związane z kulturą. Zarówno forma jak i funkcja muzeum budują tożsamość, stają się one miejscami poza czasem, wyjętymi jakby z rzeczywistości. Michel Foucault nazywa je heterotropiami, miejscami, w których obowiązuje zupełnie inny „czas”. Łączą one tradycje estetyczne i kulturowe.
\end{abstract}

Dzieło według fenomenologicznej definicji Romana Ingardena posiada punkty niedookreślenia [Ingarden 1966]. Przestrzeń miejska czy przestrzeń architektoniczna, którą także możemy traktować jako dzieło ze względu na jej cechy estetyczne i wartości artystyczne, których jest nośnikiem w kontekście społecznym, potrzebuje dopełnienia przez odbiorców, użytkowników. Ingarden pisze, że niezbędni są oni do dookreślenia dzieła. Przez odbiorców dzieło się konkretyzuje. Tak jakby nie istniało, było niepełne bez wyobraźni i inwencji odbiorcy, tego, co wnosi on wraz ze swoją obecnością. Przestrzeń, którą zastajemy możemy zmieniać. Od nas zależy jej psychologiczna wartość. Od akceptacji czy odrzucenia. Miejsca takie jak muzea sztuki, ze względu na swój charakter jako pewnego rodzaju znaku w przestrzeni, stają się „land markami”, znakami szczególnymi w przestrzeni miasta, które są elementami decydującymi o jego czytelności. Kulturalna mapa miasta jest swoistą mapą mentalną przeznaczoną dla ludzi, którzy interesują się zagadnieniami kultury czy sztuki, dlatego przestrzenie związane z muzeami żyją własnym życiem i są niezwykle ważne w kształtowaniu tożsamości, podobnie jak biblioteki. Uniwersalny przekaz, łączenie pokoleń, niwelowanie różnic społecznych, funkcja edukacyjna, poczucie wolności wyobraźni i budowanie miasta nie tylko jako przestrzeni, ale i pewnej esencji miejskości - taką rolę pełni sztuka. 
Oświeceniowi encyklopedyści stworzyli definicję muzeum, bardzo szeroka, jak napisał w swojej książce o muzeach profesor Kiciński: „(...) Legrand i Molinos [idąc za Diderotem i d'Alambertem przypis autorki] określaja muzeum jako uniwersalny pojemnik, sume wiedzy ludzkiej i sztuki, działajacy jednocześnie jako biblioteka i światynia pamięci, miejsce studiowania, poznawania i tworzenia piękna, miejsce które w ten sposób może stać się teatrem i audytorium" [Kiciński 2011, s. 22 ]. Jak pisał Czesław Miłosz w wierszu Zaklęcie [Miłosz 1981, s. 336]:

\section{„Piękna i bardzo młoda jest Filo-Sofija \\ I sprzymierzona z nia poezja w stużbie Dobrego. \\ Natura ledwo wczoraj święciła ich narodziny, \\ Wieść o tym górom przyniosty jednorożec i echo. \\ Stawna będzie ich przyjaźn, ich czas nie ma granic."}

Przytoczyłam tu słowa poety, który swój wiersz poświęcił pochwale ludzkiego rozumu. Muzeum, jak rozumieli je oświeceniowi myśliciele, jest właśnie świątynią ludzkiego umysłu. Ta definicja jest obecnie bardzo aktualna i choć jest w pewnym sensie utopijna, w obecnych czasach wszyscy ci, którzy myślą o mieście jako o ludziach w nim mieszkających, o ich potrzebach, o edukacji i integracji, a jako architekci mają szansę ubrać w formę pewne abstrakcyjne pojęcia, chociażby „wolność”, chętnie potraktowaliby ją jako syntezę swoich przemyśleń na ten temat.

Odbiorcy takich przestrzeni są bardzo zróżnicowani, dlatego traktuje się je jako ważny element integracji w mieście. Jak pisze w swojej książce profesor Kiciński - w XX w. nastąpiła zmiana statusu społecznego odwiedzających muzea. Odbiorcami sztuki przestali być jedynie przedstawiciele elit społecznych i artyści kopiujący dzieła mistrzów „Od czasów impresjonizmu, a tym bardziej - w czasach awangardy - pojawiaja się w muzeach miłośnicy dyskusji i polemik" [Kiciński 2011, s. 27]. Zdarzają się oczywiście głosy kwestionujące rozumienie współczesnego języka sztuki przez tak masowego odbiorcę, ale jednak powszechny dostęp do muzeów, bibliotek, czy mediatek jest jednym z największych dobrodziejstw naszych czasów. "Biblioteki i muzea - niezwykle ważne dla kultury człowieka instytucje, służące przechowywaniu wiedzy i pamięci, od wieków istniały obok siebie albo też tworzyły wspólny organizm." [Kiciński 2011, s. 79]. Biblioteki są podobnie jak muzea miejscem spotkań i interakcji.

Sama forma muzeum, kiedy to $\mathrm{w}$ XX w. poszukiwano uniwersalnego sposobu wystawiania dzieł sztuki, stworzenia elastycznego wnętrza dla możliwości prezentacji różnych jej gatunków, stała się inspiracją dla architektów. Przytoczyć tu można niezwykle pionierski i rewolucyjny projekt Oskara Hansena i Stanisława Zamecznika na rozbudowę Zachęty, gdzie architekci zaproponowali szklany kubik z ruchomymi ścianami, regulującymi nie tylko powierzchnię wystawienniczą, ale i doświetlenie. Centrum Pompidou jest w jakimś sensie spadkobiercą tych przemyśleń polskiego architekta. Profesor Kiciński pisze także o tym, że w obecnych czasach sztuka przekroczyła granice obiektów muzealnych [Kiciński 2011]. To co proponował Hansen i to co zostało zrealizowane w Centrum Pompidou, gdzie nastąpiła integracja wnętrza, a także poszukiwanie relacji wnętrza z ze- 
wnętrzem, było jednym z pierwszych kroków ku przekroczeniu bariery „ściany, ramy” muzeum.

Różnego rodzaju performanse, instalacje na placach miejskich, a także działania artystów w przestrzeni miejskiej są niezwykle wartościowym elementem współczesnej kultury.

Lata 20. i 30. XX w. były okresem rozwoju konstruktywizmu, rozważania twórców dotyczyły przestrzeni, relacji przestrzennych między rzeźbą czy architekturą a otoczeniem. Katarzyna Kobro i Władysław Strzemiński podjęli się krytyki konstruktywizmu tworząc teorię unistyczna, postulującą jednorodną przestrzeń. Interpretowali ją jako próżnię, którą rzeźba powinna w sposób abstrakcyjny definiować. Unizm zakładał uniwersalną rolę artysty wydobywającego geometrię przestrzeni. Rzeźba czy architektura, które Strzemiński łączył, sugerując posługiwanie się tymi samymi proporcjami, używał nawet terminu architektonizacja rzeźby, miały być jednorodnym dziełem plastyki [Strzemiński 1975].

Powojenni artyści zwracali jednak uwagę na to, że przestrzeń nie jest jednorodna, było to nawiązaniem do zachodnioeuropejskiego surrealizmu. Tadeusz Kantor twierdził, że przestrzeń to ruch, działanie, że artysta poprzez obraz, który jest manifestacją tego działania generuje ją poprzez swój indywidualny udział. Obraz jest manifestacją życia i jego przedłużeniem. Kontynuacją tego myślenia była wystawa autorstwa Wojciecha Fangora i Stanisława Zamecznika w salonie „Nowej Kultury” w 1958 r. w Warszawie. Artyści postawili tezę, że dzieło sztuki bardzo silnie oddziałuje na przestrzeń, buduje ją. Stanisław Zamecznik umieścił optyczne obrazy Wojciecha Fangora na stelażach w taki sposób, że rzeczywistość malarska wyszła poza ramy poszczególnych dzieł. Połączył wszystkie obrazy jakby w jedną geometryczną historię, która zmieniała charakter przestrzenny czy wręcz kubaturę pomieszczenia, w którym prace były wystawiane. Dodatkowo widz stał się ważnym elementem, kimś, kto potrafi odczytać prezentowaną ekspozycję. Dało to początek polskiego myślenia o tym, jak możemy zmieniać przestrzeń i na ile widz jest nam do tego niezbędny. Kolejnym etapem była działalność Galerii Foksal, w której każda wystawa stanowiła rodzaj happeningu, performansu w przestrzeni galerii, która to w pewnym sensie stawała się autonomiczną i niezależną. Są to początki myślenia polskiego, oczywiście pod wpływem działań europejskich i światowych, na temat jak plastyka może współdziałać z widzem i jak może wprowadzać pewien autonomiczny element w przestrzeń i rzeczywistość nas otaczającą.

Eksperymenty Leona Tarasewicza w przestrzeni architektonicznej i miejskiej, mam tu na myśli malarską instalację $\mathrm{w}$ pawilonie polskim na Biennale $\mathrm{w}$ Wenecji oraz zaprojektowane na Plaza Real w Barcelonie rozrzucone kolorowe kwadraty, wpisują się gdzieś we wspomniane przeze mnie wcześniej poszukiwanie relacji sztuki, która „wychodzi z ram” i widza, użytkownika przestrzeni. Szczególnie interesujący jest projekt wykonany przy okazji wystawy sztuki polskiej w Barcelonie, która ma bogatą tradycję architektoniczno-malarską. W konserwatywnym, zatopionym w kolonializmie wnętrzu miejskim, niezwykle homogenicznym i można powiedzieć surowym miejscu, polski malarz zaproponował coś, co zmieniło diametralnie jego konotację. Grupa rozrzuconych na placu kwadratów w formie charakterystycznej dla twórczości Tarasewicza „krajki” wprowadziła element wyobraźni jako istotny czynnik budujący z jednej strony bezpieczeństwo, bo do skostniałego wnętrza 
placu wprowadziła kolor, z drugiej pewną tajemnicę połączoną z ekscytacją. I choć to właśnie konserwatyzm najczęściej kojarzymy z bezpieczeństwem, to właśnie to oderwanie od korzeni i stworzenie zupełnie nowej jakości, dało szansę wielonarodowościowemu tłumowi odwiedzającemu to miejsce, by niezależnie od własnej przyniesionej tu tradycji poczuł się swobodnie. Uniwersalność sztuki przyczyniła się do złamania bariery psychologicznej i zainspirowała do zabawy. Psychologowie uważaja że człowiek ma wokół siebie rodzaj „bańki powietrza" wyznaczającej jego osobistą przestrzeń, jest to obszar otaczający jednostkę o nieprzekraczalnych dla innych granicach. Ów pęcherzyk powietrza jest pewnym komunikatem społecznym. Robert Gifford definiuje, że przestrzeń osobista jest dynamicznym przestrzennym komponentem interakcji społecznych. Leon Tarasewicz zabawił się w demiurga, zaprojektował coś, co sprawiło zmniejszenie dystansu osobistego przez wprowadzenie elementu sztuki czytelnego dla większości czy może każdego z nas. Malarz testuje tu relację między geometryczną formą a materią malarska, jednocześnie nadaje jej poetycki przekaz. Jest to rodzaj myślenia o malarstwie jako o iluzji. Czwartym wymiarem projektu jest wyobraźnia. Zaangażowanie wyobraźni i intelektu przybliżyło drugiego człowieka jako kogoś, z kim wspólnie możemy się bawić, żartować, kogoś kto jest do nas podobny. Nasze postrzeganie połączone jest zawsze z oceną emocjonalna, estetyczną i tym czy dana rzecz jest użyteczna. Przemieniony przez Tarasewicza Plaza Real jest wbrew pozorom niezwykle użyteczny - skojarzenia, jakie człowiek może mieć z wykorzystaniem grupy kolorowych kwadratów oddalonych od siebie o parę kroków są właściwie bliskie nieskończoności. Tu psychologowie społeczni posłużyliby się terminem afordancji, który oznacza potencjał miejsca. Oskar Hansen pisze w swojej książce Zobaczyć świat o zdarzeniach i tle zdarzeń, nadając głębszą treść pozornie przypadkowym sytuacjom, w pewnym sensie estetyzuje rzeczywistość wyławiając z chaosu coś, co nabiera sensu ze względu na głęboki humanizm i walory plastyczne [Hansen 2005]. Świadomość postrzegania struktur wizualnych, czy w ogóle świadome bycie, czy też bycie świadomym człowiekiem powoduje, że nie pozwalamy na ingerencję we własny świat integralnie związany z naszą wyobraźnią i pozostajemy wolni. „Imago mundi" jak pisze Christian Norberg-Schulz - świat wyobrażony - jest nam równie niezbędny jak podstawowe potrzeby egzystencjalne [Norberg-Schulz 2000], a sztuka według Malraux "rodzi się dokładnie z fascynacji tym, co nieuchwytne, z odmowy kopiowania otaczajacych nas zjawisk, z chęci wydarcia form ze świata, któremu człowiek podlega, aby je wprowadzić w świat, w którym sam rzadzi" [Szmidt 1981].

Obrazy Nikifora są niemal czystą kreacją architektoniczną która dokonuje się na kartce papieru, są konsekwencją przeżyć estetycznych ich autora i dowodem na to, jak silnym czynnikiem dla wrażliwego człowieka jest wyobraźnia. Profesor Sławomir Gzell w swojej książce O Architekturze. Szkice pisane i rysowane przedstawił obrazek, sytuację, której głównym bohaterem jest Nikifor: „Krynica Górska. Niedaleko domu „Patria” Nikifor maluje w przytomności wycieczki warszawskich gimnazjalistów. Obstapiliśmy budkę, w której siedzi przy stoliku, i obserwujemy co robi. A on co chwila podnosi głowę i patrząc przez nas, oglada pejzaż miasta, ale chyba nie tego, które jest wokót nas. Kolorowy krajobraz rosnacy na kartce papieru to przecież nie Krynica - tyle widzimy. No i jaki to krajobraz! Myślałem już wtedy o architektonicznych studiach i styszałem 
o perspektywie, proporcjach, cieniach, o pracy architektów i malarzy, o całym tym intelektualnym wyposażeniu twórców krajobrazu. A tu coś innego, poważnie ciagnione linie nie w tym kierunku, znaczaco stawiane punkty nie w tych miejscach, kolor kładziony nie taki, jak chciałby rozum widza, ale taki, ̇̇e w tamtym miejscu i o tamtej porze inny nie mógł być." [Gzell 2014, s. 34].

Można tu nawiązać znowu do wiersza Czesława Miłosza o sile ludzkiego rozumu: „On ponad to, co jest, wynosi, co być powinno"[Miłosz 1981, s. 336].

Cała psychologiczna warstwa relacji sztuka - wyobraźnia zbliża nas do tego, co możemy określić „naszym miejscem” - „W pewnym sensie każdy, kto wybiera sobie w przestrzeni miejsce, gdzie się osiedla i żyje, jest twórca przestrzeni ekspresyjnej. Nadaje swemu otoczeniu znaczenie przez asymilowanie go do swoich celów, równocześnie zaś przystosowuje się (akomoduje) do oferowanych przez nie warunków." [Norberg-Schulz 2000, s. 11]. Leon Tarasewicz sprawił że Plaza Real jest takim miejscem.

Odmienny od Tarasewicza pogląd na potraktowanie przestrzeni miejskiej jako narzędzia oddziaływania społecznego ma Krzysztof Wodiczko. Performer znany w Polsce ze swoich projektów z lat 80. XX w., który wyemigrował z kraju do Stanów Zjednoczonych i Kanady i już na emigracji zajął się wykorzystywaniem przestrzeni miejskiej, jej charakterystycznych elementów, budynków, pomników, miejsc silnie wpisanych w tożsamość miasta i społeczeństwa do realizowania swoich projekcji, w których lokalnym, ale i aktualnym w danym momencie problemom, nadaje artystyczny wymiar. Wodiczko uważa, że "Miasto jest scena i stawka demokracji" [Czubak 2011, s. 007]. Bożena Czubak we wprowadzeniu do książki o działaniach artysty Sztuka domeny publicznej pisze: „W sztuce rozumianej jako praktykowanie demokracji, nie chodzi o to, żeby sytuować sztukę w publicznej, czyli ogólnodostępnej przestrzeni, ale by za jej pomoca dziatać na rzecz publicznej domeny, która ma szersze, polityczne i filozoficzne znaczenie" [Czubak 2011, s. 007]. Wymowa projekcji przygotowywanych przez Krzysztofa Wodiczkę ma zawsze kontekst społeczno-polityczny, ale odnosi się do indywidualnych dramatów poszczególnych ludzi. Projekty składają się z projekcji i warstwy dźwiękowej, gdzie konkretne, choć anonimowe osoby, opowiadają o swoich problemach. Przez historyk sztuki, Marię Annę Potocka, Wodiczko określony został mianem „psychologa społecznego, terapeuty $i$ artysty pracujacego w materiale społecznym" [Wodiczko 2005]. Wodiczko realizuje swoje projekcje w różnych miastach świata, trzy polskie realizacje to projekcja na Wieży Ratuszowej w Krakowie, zaprezentowana w 1996 r., poruszała ona temat wykluczenia osób uzależnionych, kobiet przeżywających dramat przemocy domowej oraz bezdomnych, a także dwie zrealizowane w Warszawie - w 2005 r. - na gmachu Zachęty Narodowej Galerii Sztuki, dotycząca nierównego statusu społecznego kobiet, ich dramatów związanych z przemocą psychiczną i fizyczną i kolejna w 2008 r. - na pomniku Adama Mickiewicza, w rocznicę zdjęcia z afisza Teatru Narodowego przedstawienia „Dziadów” w 1968 r., co było początkiem wydarzeń marca $1968 \mathrm{r}$.

Kiciński o muzeach, które budują tożsamość mówi następująco: „Lokalizacja muzeum w miejscu i obszarze decydujacym o tożsamości miasta czy kraju wciaga muzeum w interakcje z catym obszarem. Usytuowanie muzeum o charakterze budującym poczucie tożsamości nobilituje z kolei miejsce i rejon lokalizacji" [Kiciński 2011, s. 44]. W Krakowie w ciągu ostatnich nieco ponad 
dwudziestu lat powstały dwa obiekty, związane z wybitnymi osobowościami łączonymi z tym miastem, myślę tu o Centrum Manggha poświęconym Feliksowi Jasieńskiemu oraz Cricotece, która jest Ośrodkiem Dokumentacji Sztuki Tadeusza Kantora. Oba budynki, powstały po mniej prestiżowej stronie Wisły i przyczyniły się do podniesienia jej rangi oraz wciągnięcia jej w pewien rodzaj miejskich interakcji. Centrum Manggha, które powstało z inicjatywy reżysera Andrzeja Wajdy, zaprojektowane przez Aratę Isozakiego, przy współudziale architekta krakowskiego Krzysztofa Ingardena, jest przykładem łączenia tradycji estetycznej. Wpisane w kontekst krakowskiego krajobrazu, dzieło japońskiego architekta, wypływa z zupełnie innej kultury, ale ze względu na wrażliwość na piękno otoczenia zakorzenioną w tradycji japońskiej, świetnie się z nim komponuje. Arata Isozaki zbudował kameralny budynek nawiązujący do uniwersalnych skojarzeń z rzeką. Elementy tradycyjne dla architektury japońskiej, jak jasna struktura i otwarcia na krajobraz, mają odbicie w metaforze łodzi odwróconej na brzegu i fali kojarzonej z Wisłą. Użyte z ogromną wrażliwością materiały są syntezą charakteru miejsca - wody i odbijającego się w niej nieba. Poetycki przekaz architektury wynika z uniwersalności i otwarcia się na różne wpływy, łączenia sposobów podejścia do krajobrazu, formy i funkcji czerpiących z różnych tradycji projektowania.

Estetyka i piękno nie są aspektami zamkniętymi w jednym kręgu kulturowym. Taki był także przekaz sztuki Tadeusza Kantora, patrona zaprojektowanej na Zabłociu przez Stanisława Deńkę Cricoteki. Pomysł na Cricotekę wywodzi się z działań malarza i performera jakim był Kantor, a Deńko zaczerpnął go ze szkiców Tadeusza Kantora, bodajże do jednego zsurrealistycznych performansów, czy fragmentu scenografii sztuki teatralnej. Pierwowzorem formy obiektu architektonicznego był „stół”, tu przez architekta i jego zespół potraktowany jak nadnaturalny właśnie element scenografii miasta. Niezależnie od inspiracji, powstała Cricoteca jest przykładem architektury na pograniczu sztuki. Wyniesienie galerii ponad stare dziewiętnastowieczne budynki elektrowni, ale nawiązanie materiałem do tradycji tego miejsca poprzez użycie perforowanej blachy cortenowej i zastosowanie „sufitu” z luster, które kojarzą się z działaniami teatru Cricot 2, prześmiewczej, surrealistycznej rzeczywistości, grupy teatralnej, w której aktorami byli artyści. Nazwa Cricot czyli „To Circ” czytane wspak. Stąd niekonwencjonalna forma, zmuszenie odwiedzającego Ośrodek Dokumentacji Sztuki Tadeusza Kantora do wykonania pewnej pracy, wejście po schodach na poziom galerii jest śluzą psychologiczną, niezbędną dla każdego muzeum, tym, co odcina nas od codzienności, a wprowadza na „wyższy poziom”, poziom sztuki. Michel Foucault w książce Inne przestrzenie mówi o miejscach na wpół realnych nazywając je heterotropiami. Są czymś na pograniczu utopii, ale mają swój komponent w postaci realnej przestrzeni. Występują poza czasem i niosą przekaz pewnej magiczności. Do takich miejsc Foucault zalicza muzea i biblioteki, w których czas spiętrza się, ponieważ stają się rodzajem powszechnego archiwum, ale same pozostają poza czasem. "Heterotropia zaczyna funkcjonować w petni wtedy, gdy ludzie znajdują się w sytuacji absolutnego zerwania ze swoim tradycyjnym czasem" [Foucault 2005, s. 123]. Cricoteka $\mathrm{w}$ swojej formie surrealistycznej przestrzeni, gdyż zwierciadło z jednej strony jest utopia, bo samo w sobie jest światem nierealnym, z drugiej zaś jest heterotropia, bo odbija mnie i realny świat, w którym w danym momencie się znajduję, wprowadza nas w pewien sposób 
w na wpół realny świat teatru. Spiętrzenie znaczeń, którymi posłużył się architekt Stanisław Deńko jest na pewno bliskie ideom patrona tego obiektu, Tadeusza Kantora.

Przestrzeń miejska składa się ze zdarzeń. Architektura - muzea, biblioteki - stają się takimi zdarzeniami w przestrzeni miejskiej. Ewa Rewers w swojej książce Post-polis. Wstęp do filozofii ponowoczesnego miasta [Rewers 2005] nawiązując do Heideggerowskiej teorii zamieszkiwania (budowanie związane jest z zamieszkiwaniem) i zarazem istoty języka, jako tej sfery kultury, która wyznacza nasz osobisty obszar i rozumienie rzeczywistości, zwraca uwagę, że miasto nie jest tylko architektonicznym tłem zdarzeń i że ludzkie odczuwanie miasta może być bliskie opisowi literackiemu. Miasto z opisu literackiego jest czymś na pograniczu zapisu spostrzeganej przestrzeni i psychologii. Roman Ingarden mówi o różnych wyglądach dzieła architektury w zależności od miejsca, z którego na nie patrzymy i czasu, w którym to się dzieje. Dzieło architektury nie ma niemal nic wspólnego z fizycznością choć jest fizycznym obiektem. Dlatego, i centrum Manggha, które stało się świetną realizacją zamysłu Feliksa Jasieńskiego zafascynowanego sztuką japońska, zaprojektowane przez Japończyka i Cricoteca, która przywołuje w wyobraźni temperament i wyobraźnię Tadeusza Kantora stają się zdarzeniami niemal literackimi w przestrzeni Krakowa. Plaza Real w Barcelonie jest poetycko malarskim zdarzeniem generującym kolejne już nasze własne zdarzenia. Być może najistotniejsza jest właśnie ta nieuchwytność, niuans. Tożsamość jest naszą własną ciągłościa, ale i przynależnością do grupy ludzi, którzy myślą podobnie do nas. Chcemy się odróżniać, ale zarazem jesteśmy ciekawi innych. Tożsamość to nasza kultura, nasz język, ale i otwartość. Sztuka jest wiarą w rozum i wyobraźnię.

Fenomenologicznie każde dzieło jest niedookreślone, można je kontynuować, ale tylko do momentu, kiedy nie naruszamy jego głębokiego sensu. Oskar Hansen pisał, że przekroczenie ludzkiej percepcji powoduje chaos. Człowiek i jego psychologia staje się dla twórcy miarą. Oświecenie było wiekiem rozumu, po Renesansie kolejną epoką gdzie podstawą była wiara w człowieka i jego możliwości.

Tożsamość miejsca wynika z zakorzenienia - to jedna z definicji, druga mówi o tym, że o tożsamości miejsca decydują ludzie, społeczności tworzą tożsamość związaną z miejscem, a otwartość i twórczość jest podstawą kształtowania takiej tożsamości. My tworzymy miejsca jako odbiorcy, dlatego artyści wykorzystują ich potencjał, by wnieść swój przekaz.

\section{Bibliografia}

Czubak B., 2011, Sztuka domeny publicznej. Art of the Public Domain, Państwowa Galeria Sztuki, Sopot.

Foucault M., 2005, Inne przestrzenie, C.E.E.O.L.

Gzell S., 2014, O Architekturze. Szkice pisane i rysowane, Blue Bird, Warszawa.

Hansen O., 2005, Zobaczyć świat, Zachęta Narodowa Galeria Sztuki, Warszawa. 
Ingarden R., 1966, Przeżycie, dzieło, wartość, Wydawnictwo Literackie, Kraków.

Kiciński A., 2011, Muzea. Zagadnienia rozwoju i projektowania; polska perspektywa, Oficyna Wydawnicza Politechniki Warszawskiej, Warszawa.

Miłosz Cz., 1981, Poezje, Czytelnik, Warszawa.

Norberg-Schulz Ch., 2000, Bycie, przestrzeń, architektura, Wydawnictwo Mirator, Warszawa.

Rewers E., 2005, Post-polis. Wstęp do filozofii ponowoczesnego miasta, Towarzystwo Autorów i Wydawców Prac Naukowych „Universitas”, Kraków.

Strzemiński W., 1975, Pisma, Zakład Narodowy im. Ossolińskich, Wrocław.

Wodiczko K., 2005, Projekcje publiczne. Public projection. 1996-2004, Muzeum Sztuki Współczesnej, Kraków.

Border - line of art and architecture. Urban space as an important factor of shaping identity

\section{ABSTRACT}

French Encyclopedists had defined museum as a sum of human knowledge and art. A place which could become a theatre or an auditory. Professor Andrzej Kiciński wrote in his book about problems of designing museums that on one hand libraries and museums are the main elements that define identity and on the other the city landscape is shaped by their forms. The receivers of such spaces are kind of community which creates a new intellectual value because of sensitiveness for contemporary artistic and also for social problems.

XX century was the age when new abstractive art appeared. The works of art were not the only artefacts. At that time a new way of communication with receivers of art was used by artists. Performances and installations were engaging spectators by mutual interactions. Art came out of the frame of the building of the museum or beyond the frame of the picture and became a kind of event in the city space. Polish artists like Leon Tarasewicz and Krzysztof Wodiczko created just the same way. The message of work of art became the more important the more the art was engaged in a common and political problems or in relation between people from the different cultural circles.

The architecture which also became an event in the urban space needs people to make it more real. Museums are landmarks on the mental map of the city, recognized by people who are close to the cultural subjects. The form and the function of museums are building the self-identity associated with ideas. These are places out of time and out of the everyday reality, named by Michel Foucault as heterotrophy. Museums connect different esthetical and cultural traditions.

mgr inż. arch. Anna Rathman, 2007 r. - dyplom magisterski na Wydziale Architektury Politechniki Warszawskiej pod kierunkiem prof. ndzw. dr. arch. Marka Świerczyńskiego; w latach 2007-2009 zwiąana z pracownia architektoniczną Grupa 5; w latach 20092011 wspótpracowała jako dziennikarz z redakcja dziennika „Polska The Times"; publikowała teksty na portalu Archirama.pl wydawanym przez wydawnictwo Architektura-Murator oraz w miesięczniku "Architektura”; w 2013 r. rozpoczęta studia doktoranckie na Wydziale Architektury Politechniki Warszawskiej pod opiekq naukowa prof. ndzw. dr hab. arch. Anny Dybczyńskiej-Bułyszko; od 2014 r. asystent-praktykant w Pracowni Projektowania Zespołów Mieszkaniowych na Wydziale Architektury Politechniki Warszawskiej. 